\title{
14
}

\section{CHINA TELECOMMUNICATIONS TRANSFORMATION IN GLOBALIZATION CONTEXT}

\author{
A Structuration Perspective
}

Ping Gao ${ }^{1}$ and Kalle Lyytinen ${ }^{2}$

${ }^{I}$ Department of Informatics, Copenhagen Business School, Denmark; ${ }^{2}$ Department of Information Systems, Weatherhead School of Management, Case Western Reserve University, USA

\begin{abstract}
As globalization is becoming a prevailing topic, information technology and infrastructure in developing countries being non-ignorable forces of globalization has arisen the interests of scholars in information systems. Drawing on structuration theory this paper analyses China's strategy of telecommunications transformation.
\end{abstract}

Keywords: China, globalization, strategy, structuration theory, telecommunications.

\section{INTRODUCTION}

As now globalization is becoming a prevailing topic, information technology and infrastructure in developing countries being non-ignorable forces of globalization has arisen the interests of scholars of information systems. Academic researches on such a topic have begun to appear in mainstream information systems journals. As one significant example, the study about the application of geographical information systems (GIS) in India appears in MIS Quarterly (Walsham and Sahay, 1999). In this paper we study the Chinese telecommunications industry. In an international perspective, China presents an interesting case to study, being the largest potential market for telecommunications services and because of its unique economic and political environment for telecommunications reform and development. From the early 1980s, China's telecommunications industry has gone through a series of transformations. As a result, China's telecommunications industry 
achieves one the fastest developments in the globe scale. Now its subscriber numbers of mobile phone and fixed line rank the first in the world (Gao and Lyytinen, 2001; MII, 1999). But what a strategy has made China's telecommunications sector achieve such a big success, and why China has adopted such a strategy? These are the research questions of this paper.

There are many publications about China's telecommunications industry (Gao and Lyytinen, 2000; 2001; Mueller and Tan, 1997; Tan, 1994; 1999). But except for Zhang (2001; 2002) who uses North's (1990) institutional theory as an analytical tool, others focus on fact-finding and description. According to North, institutions are rules and constraints that structure individual interaction in political, economic and social affairs, like regulations and policies. Zhang argues that for the Chinese telecommunications industry there exist several institutions enacted by varied organizations, e.g. governmental branches, World Trade Organization (WTO), etc. Their enforcement is through a bargaining mechanism with strong political involvements. Different from Zhang who examines the implementation of different institutions or policies from the interaction between organizations as policy-makers, in this paper we investigate how the central government of China formulates its telecommunications transformation strategy. We challenge the existing position that the negotiating mechanism of decision-making characterized by China's political system has restricted the telecommunications reform (Mueller and Tan, 1997; Tan, 1994; 1999; Zhang, 2002). We insist that the centralized administrative system allows the central government to comprehensively consider the strategy environment, which enables it to adopt a proper strategy that is to gradually carry out telecommunications transformations by balancing requirements from technology advance and restrictions from telecommunications development and economic, political reform progress.

We address our arguments by drawing on the structuration theory of Giddens $(1979 ; 1984)$. Structuration theory defines the structure of a social system and agency as a duality, which means "the structural properties of social systems are both the medium and the outcome of practices that constitute those systems" (Giddens, 1979: p.69). Structuration theory has been widely used in management studies to examine the change mechanism of social systems by taking these special social designs as structures, for example the inter-organization network (Windeler and Sydow, 2001). In this paper we define China's telecommunications market as a structure, and elaborate its transformation process which represents the reform strategy. Our idea is developed through six sections. Following this introduction section, the second section defines telecommunications reform strategy. The third section lays out theoretical grounding. The fourth section is methodology. The final two sessions describe analytical results, and derive conclusion. 


\section{CONCEPTUAL PRELIMINARIES}

By examining the experiences of reforming the old PTT1 systems in the developed world, Noam and Kramer (1994) conclude a telecommunications reform strategy has four aspects: liberalization, devolution, consolidation, and deregulation. Liberalization means introducing competition into a monopolized market. Devolution is a policy of splitting the monopoly structure. Consolidation is the opposite strategy to devolution. Deregulation means reducing government's intervention in market.

While deregulation is the main trend of telecommunications reform from long term of view, competition does not necessarily result in deregulation at all stages of reform. The role of regulation is even more crucial in the market liberalization phase than it was before. The experience has indicated that a wide change in the degree and a large difference in patterns of regulation have been presented with time evolving (Collins and Murroni, 1997). Also the institutional setting in regulation must change to adapt to market variation.

We revise Noam and Kramer's identification on national strategy for telecommunications reform, and define it as including three approaches: liberalization, reregulation and restructuring. Reregulation refers to the change in regulatory contents and patterns (deregulation, asymmetric regulation, etc), and in institutional settings. The restructuring includes devolution and consolidation.

\section{THEORETICAL GROUNDING}

\subsection{Structuration Theory}

The structuration theory defines the structure and agency as a duality. By definition of Giddens $(1979 ; 1984)$, structure is the specific type of rules and resources or capacities recursively implicated in social reproduction, and human agency is the capacity to make a difference. For duality, Orlikowski and Robey (1991) interpret it as: the structure of social systems is created by human action, and then shapes future action. Agents in their actions constantly produce and reproduce the social constructs, which both constrain and enable them. The process that the duality of structure is reproduced over time and space is defined as structuration. Linked by modalities, which are the knowledge and resources accessible to actors, the social structure and human interaction are both broken down into three dimensions (Figure 1).

\footnotetext{
${ }^{1}$ PTT (Post, Telegraph and Telephone) is traditional state network operator. When regulatory functions are split up it is referred to as PTO (Public Telecommunications Operator).
} 
When people act in organizations through modalities, they create and recreate three fundamental elements of social interactions and structures. As Walsham (1993, p.61) explains it:

Firstly, human communication involves the use of interpretive schemes which are stocks of knowledge that human actors draw upon in order to make sense of their own and others' actions. They thereby produce and reproduce structures of meanings which are termed structures of signification. Secondly, human agents utilize power in interaction by drawing on facilities such as the ability to allocate material and human resources; in so doing, they create, reinforce or change structures of domination. Finally, human agents sanction their actions by drawing on norms or standards of morality, and thus maintain or modify social structures of legitimation.

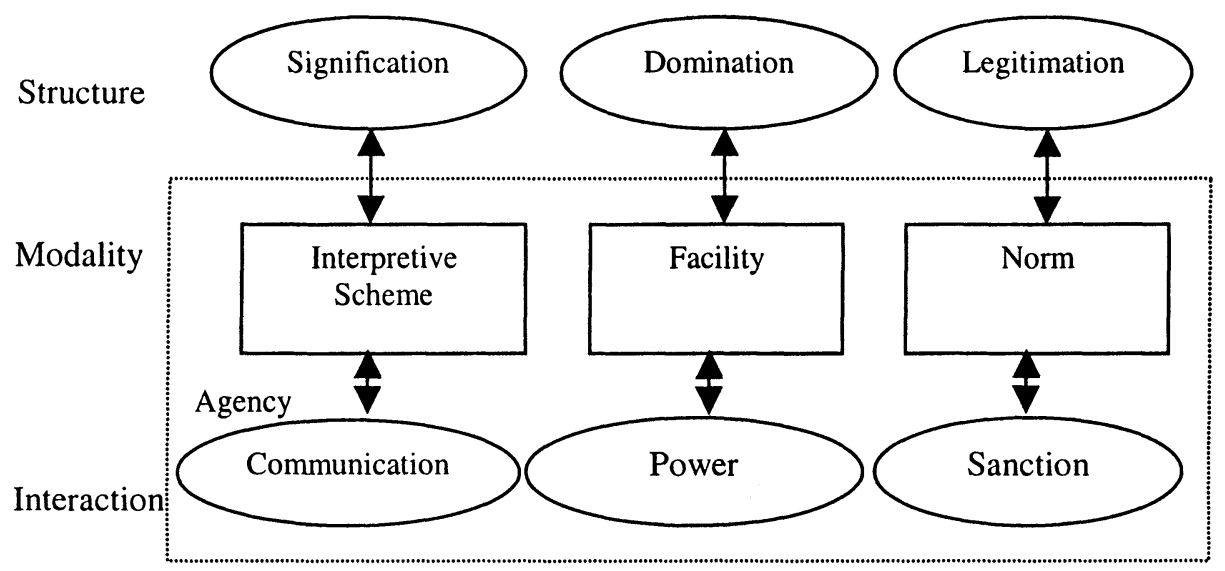

Figure 1. The duality of structure and action (Source: Giddens 1984)

\subsection{Analytical framework}

We accommodate the structuration theory to studying China's telecommunications reform strategy. The characteristics of a structurational model can be described in term of its definition on key concepts of structuration theory like structure, modality, actor and action (Walsham, 1993). We define the Chinese telecommunication market as the structure to be studied. The actor designing and then realizing the special structure is the state government. The structure and its formulation (action) constitute a duality: the structure characteristics affect the action, and in turn the structure can be modified through action which results in a new structure that is the basis of next step change. The strategy can be described by structure and action together, as shown in Figure 2. The distance denotes the change scale in ordinate, and time period in abscissa. 


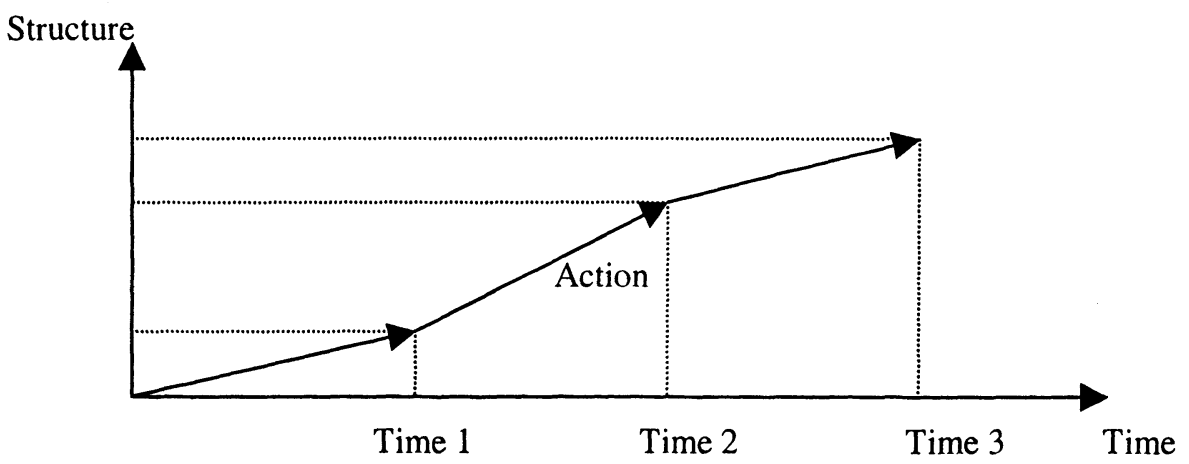

Figure 2. Strategy formulation process

The structure has three dimensions of signification, legitimation and domination. In the case of the Chinese telecommunications reform strategy, the signification is the meaning and characteristics of market structure. Legitimation is the generally accepted form of structure, or the opinion of what it should be. Domination is the economic, political, administrative, and technological ability to change or maintain a structure. The action is based on the interpretation on structure through modality. We assume the modality can be divided to several elements. From international experiences, we define them as the situations of technology advance, telecommunications development, macro economic and political environment, and international telecommunications reform (Gao and Lyytinen, 2001). Our structuration model of analysis is shown in Figure 3.

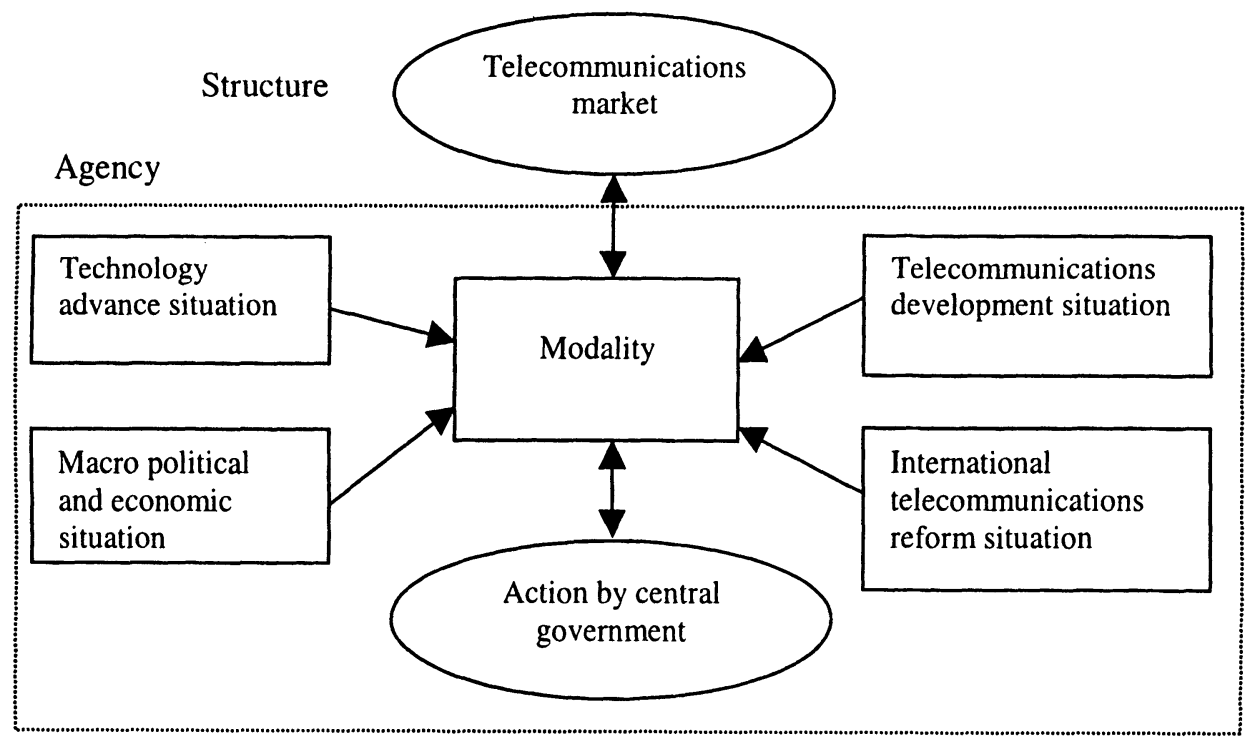

Figure 3. Structuration framework of the Chinese telecommunications market 


\section{METHODOLOGY}

Drawing on structuration theory, this paper presents a longitudinal case study. Structuration research is process study, which explains development and change by advancing a narrative that shows how it comes to be or is brought about (Holmes and Poole, 1991). To understand the structuration, the researchers need to examine the unfolding process of structure. Hence structuration research must include longitudinal studies (Sydow and Windeler, 1998). Case studies enable researchers to look at phenomenon in depth, which is necessary to unearth the structuration process (Benbasat et al., 1987).

Data are collected from different ways. One option is field observation of structuration. Another method is to use archival documents that preserve time ordering of events to reconstruct a historical account of the structuration of technology. The third way is to conduct interviews so as to get the subjects' point of view concerning what structures and structuring mean from their perspectives. The first author of this paper had been a senior analyst in the affiliated consulting institute of China's Ministry of Posts \& Telecommunications (MPT) for five years till the end of 1997. After 1998 when he moved to Europe, China's telecommunications reform has been his following-up project. He has kept a pragmatic network with the Chinese telecommunications industry, which enabled him to reach update data. Except browsing the official newspapers of China and having regular email and telephone communications with his previous colleagues who are still doing official consults to the Chinese telecommunications industry, he visited China at least one time per year to do field investigation. Especially at the end of 1998 when China was discussing its third round of reform, he was in China for one month, and interviewed people who were working in three panels to draft the reform plans for the reference of the State Council.

\section{RESULTS}

The Chinese telecommunications sector began to undergo major changes in the early 1980s by four stages. In the languages of structuration theory, China's telecommunications reform strategy is summarized in Table 1. 
Table 1. Structure and reform strategy of China's telecommunications industry

\begin{tabular}{|c|c|c|c|c|}
\hline & Signification & Domination & Legitimation & $\begin{array}{l}\text { Action } \\
\text { (Strategy) }\end{array}$ \\
\hline $\begin{array}{l}1^{\text {st }} \\
\text { stage }\end{array}$ & Monopoly & $\begin{array}{l}\text { Poor economy and } \\
\text { telecommunications } \\
\text { basis. A user-pull market. } \\
\text { Planned economy that } \\
\text { rejected competition. } \\
\text { Reform just began from } \\
\text { the US, UK. } \\
\text { Telecommunications } \\
\text { reform was a restricted } \\
\text { topic in China. State } \\
\text { support by preferential } \\
\text { policy was used }\end{array}$ & $\begin{array}{l}\text { Natural monopoly } \\
\text { was a deep-rooted } \\
\text { norm on the globe. } \\
\text { Monopoly was } \\
\text { necessary to } \\
\text { guarantee } \\
\text { sovereignty, nation } \\
\text { security, and } \\
\text { socialism. } \\
\text { Competition was } \\
\text { acceptable for } \\
\text { equipment and VAS }\end{array}$ & $\begin{array}{l}\text { Sustain } \\
\text { monopoly in } \\
\text { network and } \\
\text { basic services. } \\
\text { Execute } \\
\text { liberalization } \\
\text { and } \\
\text { deregulation on } \\
\text { equipment and } \\
\text { VAS }\end{array}$ \\
\hline $\begin{array}{l}2^{\text {nd }} \\
\text { stage }\end{array}$ & $\begin{array}{l}\text { Monopoly in } \\
\text { basic and mobile } \\
\text { services and } \\
\text { networks. } \\
\text { Domestic non- } \\
\text { private } \\
\text { competition in } \\
\text { VAS. Full } \\
\text { competition in } \\
\text { equipment. } \\
\text { Multiple } \\
\text { regulation system }\end{array}$ & $\begin{array}{l}\text { The development level of } \\
\text { telecommunications met } \\
\text { demand of national } \\
\text { economy growth. A user- } \\
\text { push market. Technology } \\
\text { advance required reform. } \\
\text { Within a move of } \\
\text { superficial macro reform } \\
\text { the government got limited } \\
\text { power to change } \\
\text { telecommunications } \\
\text { industry }\end{array}$ & $\begin{array}{l}\text { Competition became } \\
\text { a norm in } \\
\text { international scope, } \\
\text { and was practicing in } \\
\text { global scale. A } \\
\text { limited competition } \\
\text { between state-owned } \\
\text { firms as a test of } \\
\text { future move was } \\
\text { suitable for China }\end{array}$ & $\begin{array}{l}\text { Introduce state- } \\
\text { owned } \\
\text { competitors to } \\
\text { networks and } \\
\text { basic services. } \\
\text { Set a } \\
\text { coordinating } \\
\text { mechanism in } \\
\text { regulatory } \\
\text { regime. } \\
\text { Liberalization } \\
\text { and } \\
\text { reregulation on } \\
\text { PTT }\end{array}$ \\
\hline $\begin{array}{l}3^{\text {rd }} \\
\text { stage }\end{array}$ & $\begin{array}{l}\text { Duopoly in } \\
\text { mobile and basic } \\
\text { services and } \\
\text { networks. } \\
\text { Limited, unfair } \\
\text { competition. A } \\
\text { non-neutral } \\
\text { regulatory regime. } \\
\text { Unfair regulation }\end{array}$ & $\begin{array}{l}\text { Advanced, state-wide } \\
\text { networks were formed. } \\
\text { Deep macro reform was } \\
\text { underway. Joining WTO } \\
\text { in near future was a } \\
\text { political task with the } \\
\text { highest priority. The } \\
\text { government had the } \\
\text { power to enact a deep } \\
\text { reform on } \\
\text { telecommunications }\end{array}$ & $\begin{array}{l}\text { Competition crossing } \\
\text { telecommunications, } \\
\text { televisions, and } \\
\text { computer industries } \\
\text { was accepted in the } \\
\text { world. China } \\
\text { constrained the } \\
\text { reform not beyond } \\
\text { the } \\
\text { telecommunications }\end{array}$ & $\begin{array}{l}\text { Restructuring } \\
\text { on PTOs. } \\
\text { Liberalization } \\
\text { and reregulation }\end{array}$ \\
\hline $\begin{array}{l}4^{\text {th }} \\
\text { stage }\end{array}$ & $\begin{array}{l}\text { Enforced, all- } \\
\text { round } \\
\text { competition. A } \\
\text { neutral, coherent } \\
\text { regulatory regime. } \\
\text { An unreasonable } \\
\text { market in that } \\
\text { Unicom was weak }\end{array}$ & $\begin{array}{l}\text { As a WTO member, } \\
\text { China had to publish the } \\
\text { timetable of full } \\
\text { liberalization. To further } \\
\text { adjust the market so as to } \\
\text { meet the requirement of } \\
\text { joining WTO has the } \\
\text { highest priority. }\end{array}$ & $\begin{array}{l}\text { Full competition } \\
\text { with limitation on } \\
\text { foreign capitals in a } \\
\text { gradual way }\end{array}$ & $\begin{array}{l}\text { Restructuring. } \\
\text { Timetable of } \\
\text { international } \\
\text { liberalization } \\
\text { was published }\end{array}$ \\
\hline
\end{tabular}

\subsection{Up to 1994: Liberalization and Deregulation on Equipment and VAS}

Due to its backward manufacturing industry, in 1982 China opened the equipment sector. China preferred a strategy of introducing production lines by joined-venture or foreign independent investments to directly purchase 
from abroad, which bounded the interests of foreign capitals with the Chinese market. Consequently some of domestic-made equipment has dominated China's network for its comparatively low price and competent quality (MII, 1999). China opened equipment market earlier and more intensively than most developed countries. Owning strong national manufacturing industries, they did not like foreigners to share their markets. For example, it was the late 1980s when most EU members opened terminal equipment sales to countries that have agreements of equal market access with them (European Commission, 1988).

In history the telecommunications network and services had been run under a monopoly in the global scope. This situation just began to change from the US and UK. In the US, the Modification of Final Judgment mandated AT\&T to divest itself of its local service sector before January 1984, which was regrouped under seven regional holding companies. Meanwhile AT\&T was allowed to enter into previously restricted markets like information services (Snow, 1995). In UK the market was fully liberalized in 1991 after a transition of duopoly in 1984 (Thatcher, 1999). Natural monopoly was still a general practice and legitimation in the world.

In macro economic and political context, reform on traditional socialism system and planned economy just began from non-dominant sectors. Telecommunications network was taken as an infrastructure and a basis of national economy, hence had to be under the absolute control of the state to guarantee national security and sovereignty. China's telecommunications network was extremely weak. In 1980, the telephone penetration rate was only $0.4 \%$. From economic, political and ideological perspectives, the government had no power to reform telecommunications.

To promote China's telecommunications to develop from a very poor basis, the government granted preferential policies to telecommunications sector, which was possible under the state monopoly system. The State Council approved MPT to charge an installation fee from every subscriber that corresponded to the construction cost of one line. MPT had a privilege in advancing depreciation, using foreign currency and paying tax. More than half of MPT's investment was from these supports (MII, 1999).

New telecommunications services appeared from middle 1980s. Like in most other countries, in China value-added service (VAS) like paging without high network dependence was gradually opened to competition from

the late 1980s. Currently VAS is a highly competitive market with thousands of operators (MII, 1999).

\subsection{From 1994 to 1998: Liberalization and Reregulation on PTT System}

The preferential policy and the strong market demand promoted the 
Chinese telecommunications sector to enter to a new stage. In 1994, the telecommunications development level was already equivalent to the general growth level of the macro economy (Yang, 1997). The telecommunications market shifted from a buyer's pull to a seller's push. Therefore, unlike earlier times when the overriding objective was the development speed, currently service quality improvement and tariff reduction became the new focus, which could be best realized through a competitive mechanism.

In the US, the 1996 Telecommunications Act removed all remaining restrictions on the service scope of an operator and fully liberalized the American market (Baliga and Santalainen, 1999). For the liberalization on VAS in the global scale, and on basic telecommunications in the US and UK, generally an encouraging conclusion could be derived (Council of Economic Advisers, 1999; OECD, 1995). Hence competition was becoming a prevailing norm in international telecommunications world. Most developed countries were designing their reform plans. In China the support of preferential policy of the state met strong challenge from society and other industries. Also market competition was the demand of technological innovation. The appearance of Internet arose the topic of national information highway in the world, which required the convergence of media, banking industries etc with telecommunications. In macro aspect, China was initializing a statewide governmental reform to separate enterprise management functions from government branches. The state Council was empowered to reform the telecommunications industry. Consequently the market structure was transferred from monopoly supported by preferential policies to competition.

In 1994, as a part of macro reform, the State Council reformed the PTT system. Registered as China Telecom, the operating sector of MPT was changed from a functional department of MPT to an enterprise. Meanwhile Ministry of Electronic Industry (MEI) with some other state institutions formed Unicom to compete with China Telecom all-around, and Jitong that dedicated to Internet. Some ministries jointly set up the Sino Satellite Communications and China Orient to compete ChinaSat.

At the outset these changes were just like most international practices of telecommunications reforms, which are characterized by forming a coherent regulatory regime with an independent regulator and introducing new operators. But in China these changes were superficial. Both owned by the state, China Telecom and Unicom were the only two comprehensive public operators. They had a great disparity in strength. Unicom's income was less than only $1 \%$ of China Telecom's (Gao and Lyytinen, 2000). It was an unreasonable market situation in view of fair competition and should be improved. More importantly, China Telecom was still directly under MPT's control without independent rights in finance, investment, personnel, etc. Hence China Telecom was not a real enterprise, and the MPT was not a 
"pure" regulatory authority either. On the one hand MPT could not work fairly in executing regulation but might exercises bias toward its affiliation China Telecom. On the other hand it had no enough power to intervene in the domain of other ministries for example MEI that also participated in telecommunications market. The case was the same for the whole macro reform which was a superficial make-up. To prevent political disorder, China adopted an "act after trials" policy of transformation. At this time for the first move of reform, it was not intended to fully change the current system designed for the planned economy, but to perform a pilot test for future moves.

Prevented by the reform progress at the macro level, the 1994's reform on PTT failed. To meet the regulatory demand from market liberalization, the State Council set up a Joint Conference on National Economic Informatization in 1994 to coordinate the regulatory function distributed among different institutions. In 1996 it was substituted by the National Information Infrastructure Steering Committee (NIISC), which was responsible for the formulation and implementation of plans, policies, and regulations in information industry. But the NIISC was only an interim organization without legislative status, financial means, and administrative power to efficiently execute regulation. It still had to negotiate and cooperate with other powerful governmental agencies that were in charge of China's telecommunications industry (Tan, 1999).

\subsection{From 1998 to 2000: PTOs Restructuring, Further Liberalization and Reregulation}

From late 1990s China's telecommunications development entered a new phase marked by the forming of advanced, cross-country networks (MII, 1999). But the efficiency was low and service quality remained unsatisfactory. In international aspect, competition was not only a commonaccepted norm but also put into practices. In EU, the January 1st of 1998 was the set deadline of full liberalization ${ }^{2}$ (European Commission, 1997). Adapting to technology advance characterized by network convergence, a tide of enterprise mergers crossing national boundaries and spanning industries like telecommunications, computing and media emerged. A thorough reform on telecommunications industry was also a part of China's plan of joining WTO as soon as possible. The communist party of China with the supreme power in the country set it as a political task, which had the highest priority in national strategy. A deep reform was necessary to foster a fair competition market as required by joining WTO, and improve the

\footnotetext{
${ }^{2}$ Excluding Greece, Ireland, Portugal and Spain under derogation permission. In practice there are variances in different $\mathrm{EU}$ countries in their reform progress
} 
competence of domestic operators in the forthcoming international competition.

In China, in 1998 a new round of governmental reforms started, which resulted in deep changes in the governmental system. As a result the Ministry of Information Industry (MII) was established based on MPT and MEI. MII was a coherent regulator by taking over the regulatory functions of MPT, MEI, NIISC, etc. MII was mandated with an exclusive power in administrating and regulating whole information industry.

For market transformation, the State Council set the principle as supporting the Unicom and protecting fair competition. China Telecom kept its fixed network and operations, and split mobile sector to form an independent body China Mobile. The paging sector of China Telecom whose turnover was five times of Unicom, and the mobile network of Great Wall as an army-run company were appropriated to Unicom (MII, 1999). The consolidation strategy was also applied to the satellite sector. ChinaSat, Sino Satellite Communications, and China Orient were merged to a group China Satellite. China Net was formed in 1999 by some state institutions, and the dedicated telecommunications network of the national railway sector was granted to enter into public telecommunications competition in 2000 by forming China Railway Communications. Consequently China has formed a "national fleet" composed by seven "carriers": China Telecom, Unicom, China Mobile, China Satellite, China Net, Jitong and China Railway Communications. This was the market prepared to meet for international competition (Gao and Lyytinen, 2001).

\subsection{After 2000: Liberalization to Foreign Competition and Restructuring of Market}

The fourth stage of reform was promoted by that China was formally adopted as a member of WTO at the beginning of 2001. For which China agreed to allow $49 \%$ foreign ownership in mobile communications within five years of accession; $49 \%$ in international and domestic services within six years upon accession; and $50 \%$ in VAS within two years. Foreign companies are going to enter into China within recent years, for which China believed it should re-arrange the market as preparations.

Another reason for the new round of reform was that the fair competition has not come as expected. Comparatively Unicom was still too weak to compete with China Telecom. Consequently, China Telecom was broken into two parts by areas. The northern part was composed by eleven northern provincial networks, China Net and Jitong, and took the name of China Net. The southern part was other provincial networks, and kept the name of China Telecom. Now Unicom is the only comprehensive 
telecommunications company in that its network spreads the whole country (though not strong), and it has licenses to provide all kinds of services.

\section{DISCUSSION}

\subsection{Characteristics of China's Telecommunications Reform}

In China the telecommunications reform has been carried out by governmental orders through applying administrative measures, which is different from other countries where the transformation is enacted by laws. By now the reform on China's telecommunications industry has gone through four stages and a full competition market is coming, a "Telecommunications Law" is still missing. This is the result of China's "after and trial" method in macro reform on the entrenched planned economy, which excludes the effects of laws.

In international experiences, telecommunications reform is major carried out through introducing new private competitors. In China PTO as the major reform target was split, by services firstly and by areas later. An explanation may be that this is in the consideration that the existence of a dominant operator will jeopardize the fair competition. A big firm has more power of influencing institutional environment of regulation enforcement (DiMaggio and Powell, 1983), for which China has a favourable cultural and political environment. Hence a devolution strategy was necessary.

China's ideological and political system favours that the state economy should control telecommunications. Hence in China the competition has been among state-owned operators, and a limitation is set on foreign capitals to let the Chinese companies take dominant shares in future cooperation.

Now China is still transforming towards a full competition. First, further deregulation is needed to remove the entrance barriers to allow more dedicated networks to enter into public telecommunications market. While the timetable of market opening to international capitals has been published, the restriction on domestic private capital should also be relaxed. Second, it is necessary to further deregulate the market, and change all operators to comprehensive ones like Unicom. The restriction on services for current operators should be released. The competition across areas should be encouraged. Third, the market should be restructured. Railway Communications is too weak to exist independently. Last, a convergence of telecommunications and other industries should be promoted.

\subsection{The Application of Structuration Theory}

This paper employs the structuration theory as the analytical tool in three 
aspects: defining market as a structure, describing the process of structure change as a strategy, and using modality to explain the decision maker's interpretation on structure and choice on strategy. The modality is defined as composed by four elements. Action or strategy includes reregulation, liberalization, and restructuring. The structuration theory dynamically connects different modality elements with strategy. As is summarized by Table 2, these elements have different influence on explaining the structure, and each element plays varied roles in different stages on formulating the strategy. Of all, the macro reform progress and politic consideration is decisive for strategy choice. In China, telecommunications reform has been a part of macro reform and national strategy of economy and politics, like joining WTO.

Table 2. Modality and strategy

\begin{tabular}{|c|c|c|c|c|c|}
\hline & $\begin{array}{c}\text { Technology } \\
\text { advance }\end{array}$ & $\begin{array}{c}\text { Telecommunications } \\
\text { development }\end{array}$ & $\begin{array}{l}\text { Macro } \\
\text { context }\end{array}$ & $\begin{array}{l}\text { International } \\
\text { environment }\end{array}$ & Strategy \\
\hline $\begin{array}{l}1^{\text {st }} \\
\text { stage }\end{array}$ & $\begin{array}{l}\text { Telephone } \\
\text { network. } \\
\text { Fibre was } \\
\text { used }\end{array}$ & $\begin{array}{l}\text { Poor networks. User- } \\
\text { pull market }\end{array}$ & $\begin{array}{l}\text { Planned } \\
\text { system. } \\
\text { Poor } \\
\text { economy }\end{array}$ & $\begin{array}{l}\text { VAS } \\
\text { competition. } \\
\text { US, UK led } \\
\text { reform }\end{array}$ & $\begin{array}{l}\text { Liberalization, } \\
\text { deregulation } \\
\text { on VAS and } \\
\text { equipment }\end{array}$ \\
\hline $\begin{array}{l}2^{\text {nd }} \\
\text { stage }\end{array}$ & $\begin{array}{l}\text { Internet, } \\
\text { mobile } \\
\text { network } \\
\text { Internet } \\
\text { appeared }\end{array}$ & $\begin{array}{l}\text { The development level } \\
\text { of telecommunications } \\
\text { met demand of national } \\
\text { economy growth. A } \\
\text { user-push market }\end{array}$ & $\begin{array}{l}\text { Superficial } \\
\text { macro } \\
\text { reform. } \\
\text { Fast } \\
\text { economic } \\
\text { develop- } \\
\text { ment }\end{array}$ & $\begin{array}{l}\text { Reform PTT. } \\
\text { Introduce } \\
\text { competition }\end{array}$ & $\begin{array}{l}\text { Reregulation } \\
\text { on PTT. } \\
\text { Liberalization }\end{array}$ \\
\hline $\begin{array}{l}3^{\text {rd }} \\
\text { stage }\end{array}$ & $\begin{array}{l}\text { Network } \\
\text { convergence }\end{array}$ & $\begin{array}{l}\text { Advanced, state-wide } \\
\text { networks were } \\
\text { formed. }\end{array}$ & $\begin{array}{l}\text { Deep } \\
\text { macro } \\
\text { reform. } \\
\text { Fast } \\
\text { economic } \\
\text { develop- } \\
\text { ment } \\
\end{array}$ & $\begin{array}{l}\text { Full } \\
\text { competition }\end{array}$ & $\begin{array}{l}\text { Restructuring } \\
\text { on PTOs. } \\
\text { Liberalization, } \\
\text { reregulation }\end{array}$ \\
\hline $\begin{array}{l}4^{\text {th }} \\
\text { stage }\end{array}$ & $\begin{array}{l}\text { Network } \\
\text { convergence }\end{array}$ & $\begin{array}{l}\text { A leading sector in } \\
\text { national economy }\end{array}$ & $\begin{array}{l}\text { Joining } \\
\text { WTO }\end{array}$ & $\begin{array}{l}\text { Full } \\
\text { competition }\end{array}$ & $\begin{array}{l}\text { Restructuring. } \\
\text { Fixing } \\
\text { timetable of } \\
\text { international } \\
\text { liberalization } \\
\end{array}$ \\
\hline
\end{tabular}

For future research, one possibility of improvement on this paper is to incorporate other theories with structuration theory to provide a pluralistic account of strategies by different agents (Hung and Whittington 1997; Sahay and Walsham, 1997). For example by incorporating North's institutional theory as used by Zhang (2001; 2002), an extra institutional component can be added to modality. In this way the role of different institutes on strategy formulation can be explained to a better degree, and the question why some obviously better schemes were not accepted, e.g. to combine Railway Communications with other operators, can be answered clearly. 


\section{CONCLUSION}

There is different ways to study market change. For the case of the Chinese telecommunications industry, most current studies investigate the influence of different institutes. Differently and as the first, we focus on the behaviour of the decision maker that designs the reform strategy. While previous studies have mainly focused on fact-finding and descriptions, here we demystify structuration theory and use it as the analytical basis for its strength in describing market transformation as a path dependent process. Our structuration model dynamically connects different elements of the modality with strategy formation. The concept of pluralistic components of modality can be generalized to studying other social systems, or policymaking in varied fields. We conclude that structuration theory is useful in describing the dynamic, varied influence of different elements on transformation of structure, as is telecommunications market in this paper.

We observe that varied modality elements have different influence on the reform strategy of China's telecommunications industry, and each element plays special roles in different stages. Of all, the macro reform process and national policy play a determinant role. Generally China's telecommunications transformation has been a part of the macro reform that abides by an "act after trial" motto, and greatly influenced by national policy like joining WTO. In the globalization context where a full competition is the main trend, China designs its own strategy major based on its own situation, instead of mechanically following others. China has cautiously promoted telecommunications market change in four stages.

Now China is still in the process of moving towards a full competition crossing telecommunications and other industries like media, televisions etc. According to previous experience, the advance will be determined to a large degree by macro reforms, e.g. to remove the tight control on media by the state.

\section{ACKNOWLEDGEMENTS}

The first author acknowledges the financial support of the PITNIT project led by professor Jan Damsgaard. The finial version of this paper is done when he was a researcher in PITNIT project. Please see: http://www.cs.auc.dk/research/IS/PITNIT/. 


\section{REFERENCES}

Baliga, R., Santalainen, T. Telecommunications in Transition: The US Experience, Helsinki. HeSE Print, 1999.

Benbasat, I, Goldstein, D.K., Mead, M. "The Case Research Strategy in Studies of Information Systems", MIS Quarterly, (11:3), 1987, pp.369-386.

Collins, R., Murroni, C. "Future Directions in Telecom Regulation: The Case of the United Kingdom", in Telecom Reform: Principles, Policies and Regulatory Practices, W.H. Melody (eds.), Lyngby: Technical University of Denmark, 1997.

Council of Economic Advisers. "Progress Report: Growth and Competition in U.S. Telecommunications 1993-1998", Washington DC, Feb. 8, 1999.

DiMaggio, P., Powell, W.W. "The Iron Cage Revisited: Institutional Isomorphism and Collective Rationality in Organizational Fields", American Sociological Review, (48), 1983, pp. 147-160.

European Commission, "Directive on Competition in the Markets in Telecommunications Terminal Equipment", 88/301/EEC, 1988.

European Commission, "Status Report on EU Telecommunications Policy", DGXIIV/A/1, 7 May, 1997.

European Commission, "First Monitoring Report on Universal Services in Telecommunications in the European Union", COM(1998)101, 1998.

Gao, P., Lyytinen, K. "Telecommunications in Transition: The Chinese Experience in the International Context", in Managing Telecommunications and Networking Technologies in the 21st Century: Issues and Trends, G. Grand (eds.), Idea Group Publishing, 2001.

Gao, P., Lyytinen, K. "Transformation of China's Telecommunications Sector: A Macro Perspective", Telecommunications Policy, (24:8-9), 2000, pp.719-730.

Giddens, A. Central Problems in Social Theory, Berkeley, CA: University of California Press, 1979.

Giddens, A. The Constitution of Society, Cambridge: Polity Press, 1984.

Holmes, M., Poole, M.S. "The Longitudinal Analysis of Interaction", in Studying Interpersonal Interaction, B. Montgomery and S. Duck (eds.), New York: Guilford, 1991.

Hung, S., Whittington, R. "Strategies and Institutions: A Pluralistic Account of Strategies in the Taiwanese Computer Industry”, Organization Studies, (18:4), 1997, pp. 551-575.

MII, China Telecommunications Over 50 Years, Beijing. MII, 1999.

Mueller, M., Tan, Z. China in the Information Age: Telecommunications and the Dilemmas of Reform, Westport, CT: Praeger, 1997.

Noam, E., Kramer, R. "Telecommunications Strategies in the Developed World: a Hundred Flowers Blooming or Old Wine in New Bottles", in Telecommunications in Transition: Polices, Services and Technologies in the European Community, C. Steinfield, J. Bauer, and L. Caby (eds.), Sage, 1994.

North, D. Institutions, Institutional Change, and Economic Performance, Cambridge, NY: Cambridge University Press, 1990.

OECD, "Telecommunications Infrastructure: The Benefits of Competition. Information Computer Communication Policy", Paris. OECD, 1995

Orlikowski, W.J., Robey, D. "Information Technology and the Structuring of Organization", Information Systems Research, (2:2), 1991, pp.143-169.

Petrazzini, B., Krishnaswamy, G. "Socioeconomic Implications of Telecommunications Liberalisation: India in the International Context", The Information Society, (14:1), 1998, pp.3-18.

Petrazzini, B. "The Political Economy of Telecommunications Reform" in Developing Countries: Privatisation and Liberalisation in Comparative Perspective, Westport, CT: Praeger, 1995. 
Sahay, S., Walsham, G. "Social Structure and Managerial Agency in India", Organization Studies, (18:3), 1997, pp.415-444.

Snow, M. "The AT\&T Divestiture: A 10-year Retrospective", in Beyond Competition: The Future of Telecommunications, D. Lamberton (eds.): Elsevier Science, 1995.

Sydow, J., Windeler, A. "Organizing and Evaluating Interfirm Networks: A Structurationist Perspective on Network Processes and Effectiveness”, Organization Science, (9:3), 1998, pp.265-284.

Tan Z. "Challenges to the MPT's Monopoly", Telecommunications Policy, (18:3), 1994, pp.174-181.

Tan, Z. "Regulating China's Internet: Convergence Toward a Coherent Regulatory Regime", Telecommunications Policy, (23:3-4), 1999, pp.261-276.

Thatcher, M. "Liberalization in Britain: From Monopoly to Regulation of Competition", in European Telecommunications Liberalization, K. Eliassen and M. Sjovaag (eds.), NY: Routledge, 1999.

Walsham, G. Interpreting Information Systems, Chichester: Wiley, 1993.

Walsham, G., Sahay, S. "GIS for District-Level Administration in India: Problems and Opportunities”, MIS Quarterly, (23:1), 1999, pp.39-66.

Whittington, R. "Put Giddens into Action: Social Systems and Managerial Agency", Journal of Management Studies, (31), 1992, pp.829-845

Windeler, A., Sydow, J. "Project Network and Changing Industry Practices-Collaborative Content Production in the German Television Industry", Organization Studies, (22:6), 2001, pp.1035-1060.

Yang, P. "A Calculation of China Telecommunications Development Situation", Posts and Telecommunications Soft Science Research, (39), 1997, pp.3-7.

Zhang, B. "Assessing the WTO Agreements on China's Telecommunications Regulatory Reform and Industrial Liberalization", Telecommunications Policy, (25:7), 2001, pp.461483.

Zhang, B. "Understanding China's Telecommunications Policymaking and Reforms: A Tale of Transition Toward Liberalization", Telematics and Informatics, (19:4), 2002, pp.331349.

\section{About the Authors}

Ping Gao received a Doctor of Engineering degree from Xi'an Jiaotong University in 1992. Then he worked as a consultant for the Ministry of Posts and Telecommunications of China till 1997. From 1997 he was a researcher on mobile communications standardization at University of Jyväskylä, Finland. Now he is in Copenhagen Business School as a researcher of Mobiconomy project which studies mobile commerce implementation. His research interests include telecommunications regulation and strategy, technology diffusion, mobile commerce, digital economy and knowledge management. He has been following China's telecommunications industry, and taken it as his continuous study project. Ping can be reached by e-mail at pg.inf@cbs.dk.

Kalle Lyytinen is a professor at Case Western Reserve University and an adjunct professor at the University of Jyväskylä, Finland. He serves currently on the editorial boards of several leading IS journals including, 
Senior Editor of AIS journal, Information Systems Research, EJIS, JSIS, Information \& Organization, Requirements Engineering Journal, and Information Systems Journal. He has been the former secretary and chair of IFIP 8.2. He has published over 150 scientific articles and conference papers and edited or written eight books on topics related to system design, method engineering, implementation, software risk assessment, computer supported cooperative work, standardization, and ubiquitous computing. His research interests include information system theories, computer aided system design and method engineering, system failures and risk assessment, computer supported cooperative work, nomadic computing, and the innovation and diffusion of complex technologies and the role of institutions in such processes. Kalle can be reached by e-mail at kj113@po.cwru.edu. 